\title{
International Lease Accounting and Tax Consequences: The Hong Kong Perspective
}

\author{
Daniel Ho \\ Associate Professor \\ Department of Accountancy \& Law, School of Business \\ Hong Kong Baptist University, Kowloon Tong, Hong Kong \\ Tel: (852) 3411-7539 Fax: (852) 3411-5581Ｅ-mail: danielho@hkbu.edu.hk \\ Shirley Kan \\ Senior Instructor \\ School of Accountancy, Faculty of Business Administration \\ The Chinese University of Hong Kong, Shatin, Hong Kong \\ Tel: (852) 2609-8557 Fax:(852) 2603-5114Ｅ-mail: skan@baf.msmail.cuhk.edu.hk \\ Brossa Wong (corresponding author) \\ Associate Professor \\ Department of Accountancy, Hang Seng Management College \\ Shatin, Hong Kong \\ Tel: (852) 2636-7173 Fax: (852) 2632-5092Ｅ-mail: brossawong@hsmc.edu.hk
}

\begin{abstract}
This paper investigates into the accounting and tax consequences of buying or leasing an asset in Hong Kong. If the finance rates on a borrowing and a lease are the same, it would be better to buy the asset as a taxpayer can enjoy the tax benefits through high depreciation allowances. If a taxpayer is not subject to tax, it will be better to lease the asset. The tax benefits enjoyed by the leasing company can then be passed on to the lessee in the form of reduced rental. The current practice of lease accounting is prescribed by IAS 17. The proposed "right-of-use model" suggests that all leases would give rise to assets and liabilities to lessees to the extent of the fair value of the rights and obligations that are conveyed by the leases. The suggested model is conceptually sound and may improve the quality of financial reporting.
\end{abstract}

Keywords: Taxable profits, Lease accounting, Lessee, Lessor, Operating lease, Finance lease

\section{Introduction}

It is clear that accounting standards are not formulated with taxation in mind. There has been uneasy relationship between taxable profits and accounting profits for many years (e.g., Broke, 1995; Freedman, 1995, 2004; Green, 1995; Macdonald, 1995; Sallabank and Woodgate, 1995; Whittington, 1995). Tax case (e.g. Gallagher v Jones [1993] S.T.C. 537) has raised the issue of the relationship between accountancy practice and the law as regards the computation of taxable trading profit for a taxpayer involved in a lease. There are basically two methods for a business to acquire an asset - buy it or lease it. The huge scale of leasing throughout the world means that this is a vital issue for a wide range of companies. The financial cost to the business of borrowing to buy the asset, and leasing the asset should be theoretically the same. However, both the accounting and tax consequences of buying and leasing are drastically different. The purpose of this paper is to investigate into the accounting and tax consequences of buying or leasing an equipment for a Hong Kong corporation and whether such consequences would strongly influence the business's decision as to the method by which an equipment is acquired.

\section{Literature Review on Lease Accounting}

Prior research on lease accounting has focused primarily on lessee accounting, addressing the impact of capitalizing leases; the similarity between operating leases and debt; the use of lease accounting information; and the impact of Statement 13 (FAS 13) Accounting for leases on lessees. On the other hand, the limited research on lessor accounting has focused on the impact of residual value estimates on income.

A substantial amount of research has examined the impact of capitalizing leases on financial statements. Results of studies by Imhoff et al. (1991 and 1993) and Beattie et al. (1998) suggest that capitalization of operating leases 
would significantly affect balance sheet measures such as gearing or leverage ratios and performance measures such as profit margin, return on assets and asset turnover; although the effect on performance measures is not as dramatically as that on balance sheet measures. The impact would be most pronounced for the service industry, and least pronounced for the mineral extraction industry (Beattie et al. (1998)). Moreover, capitalization of operating leases would likely alter the relative standing of firms within and across industries for gearing and other debt-related ratios, but is not as likely to alter the relative standing of firms for performance measure (Beattie et al. (1998) and Goodacre (2003)).

Numerous studies (see for example Beaver et al. (1970)) have shown that the level of debt is positively associated with equity risk. If the amount of leases also is associated with equity risk, it could be argued that leases behave similarly to debt and should be accounted for similarly. After controlling for debt levels, Bowman (1980) first documents that capital leases are positively associated with equity risk, suggesting that capital leases behave like debt in their effect on equity risk. Extending this research to operating leases, Imhoff et al. (1993) find that the present value of operating leases also is positively associated with equity risk. Similar results are found by Ely (1995), who, however, finds that the contingent fee portion of operating lease payments are not associated with equity risk, suggesting that the contingent lease payments does not behave like debt in its effect on equity risk. The final study by Beattie et al. (2000) shows that leases (operating leases in particular) appear to be partial substitutes for debt financing, with leases partially consuming debt capacity. All these findings suggest that excluding contingent fee arrangements, leases behave like debt in their effect on equity risk, and should be accounted for similarly to debt.

One of the objectives of financial statements is to aid decision making. Research on lease accounting has examined how lease accounting information is perceived and used. Hartman and Sami (1989) examine how lease usage affects loan approval decisions by asking bank loan officers to determine the interest rate they would charge and the credit rating they would assign to loan applicants with different lease usage. Results indicate that lenders are willing to lend at lower rates and assign higher credit ratings to firms that use more operating leases than capital leases, suggesting that either lenders perceive capital leases and operating leases to be economically different or lenders are misled by the accounting. The study by Breton and Taffler (1995) also suggests that stockbroker analysts do not adjust for operating leases when performing stock valuation or forecasting. However, guidance throughout Standard \& Poor's Corporate Ratings Criteria (2002) suggests that credit analysts typically adjust their debt and leverage analysis for the amount of operating leases, suggesting that credit analysts are not misled by the accounting, and they consider operating leases to be equivalent to debt. On the other hand, Gopalakrishnan and Parkash (1996) find that borrowers and lenders believe capital leases are essentially liabilities, but they hold very distinct views on whether operating leases are actually liabilities. Finally, a recent study by Beattie et al. (2006) finds that users and preparers often hold quite distinct views on how to account for leases, but they both seem to agree on some important issues as well.

Prior to the issuance of FAS 13, different models have been developed for lease accounting. In November 1976, the Financial Accounting Standards Board (FASB) issued Statement No. 13, Accounting for Leases. A number of studies have been carried out to examine the impact that Statement 13 had on equity risk, capital structure, and stock prices of lessees. By comparing the stock return variance before and after adoption of Statement 13 for 17 U.S. firms that had significant new capitalizations of leases under Statement 13, Martin et al. (1979) find that the market's assessment of firms' equity risk did not change following the adoption of a new standard requiring the capitalization of operating leases. Studies of Finnerty et al. (1980), Abdel-khalik (1981) and Murray (1982) also show similar results for numerous measurements of equity risk and multiple industries. However, in a side-by-side comparison of identical firms that differ only in their use of capital or operating leases, Abdel-khalik (1981) finds that CFOs, bank lenders, auditors, bond analysts and stock analysts tend to prefer the operating-lease firm over the capital-lease firm in terms of profitability, debt-paying ability, and ability to predict cash flows. This result seems at odds with the finding that Statement 13 had no impact on firms' equity risk, but Abdel-khalik (1981) suggests that this difference may have occurred because users of financial statements are favorably influenced in their evaluation of a company if it avoids capitalizing its leases. Although these studies suggest that Statement 13 had no impact on firm's equity risk, other studies show an impact on capital structure. Imhoff and Thomas (1988) examine how Statement 13 affected firms' choice of financing options, and find that firms mitigated the impact of Statement 13 by renegotiating the terms of lease contracts to avoid capital lease criteria. Firms also shifted their financing away from debt financing toward equity financing. Similar capital structure change in response to the issuance of a new lease accounting standard is documented in Australia by Godfrey and Warren (1995). Apart from equity risk and capital structure, the impact of Statement 13 on stock prices has been examined by El-Gazzar (1993). He finds that stock prices declined significantly for firms that would have experienced tightened debt covenant restrictions as a result of capitalization, 
and that the magnitude of decline was positively associated with the change in the tightness in debt covenant restrictions. However, no other stock price reactions to the adoption of Statement 13 have been documented, suggesting that the market's reaction to any new lease accounting standard would be minimal.

Whilst a great deal of research has been done on lessee accounting, very little research has addressed lessor accounting. The limited research focuses on the impact residual value estimates can have on income, suggesting the need for better disclosure regarding actual and expected residual value realizations (Powers and Revsine (1989) and Johnson et al. (1993)), and the need to consider upward rent reviews and tenant-specific discount rates when estimating the fair value of a lease receivable (Crosby (2003)).

\section{International Accounting Standard / Hong Kong Accounting Standard 17 Leases}

Starting from 1 April 2001, the International Accounting Standards Board (IASB), an independent accounting standard-setter based in London, UK assumed accounting standard-setting responsibilities from its predecessor body, the International Accounting Standards Committee (IASC). The Board members come from nine countries and have a variety of functional backgrounds. As stated in its website (www.iasb.org), the IASB is committed to developing, in the public interest, a single set of high quality, understandable and enforceable global accounting standards which are known as the International Financial Reporting Standards (IFRSs) that require transparent and comparable information in general purpose financial statements. In addition, the IASB co-operates with national accounting standard-setters to achieve convergence in accounting standards around the world. Currently, nearly 100 countries and regions (Hong Kong is one of the regions) require or permit the use of, or have a policy of convergence with, IFRSs.

There are no major textual differences between International Accounting Standard 17 (IAS 17) Leases and Hong Kong Accounting Standard 17 (HKAS 17) Leases. The objective of HKAS 17 is to prescribe, for lessees and lessors, the appropriate accounting policies and disclosure to apply in relation to leases. A lease is an agreement whereby the lessor conveys to the lessee in return for a payment or series of payments the right to use an asset for an agreed period of time (para. 4, HKAS 17). The definition of a lease includes contracts (sometimes known as hire purchase contracts) for the hire of an asset that contain a provision giving the hirer an option to acquire title to the asset upon the fulfillment of agreed conditions (para. 6, HKAS 17).

Lease classification is made at the inception of the lease (para. 13, HKAS 17) and the classification of leases adopted in HKAS 17 is based on the extent to which risks and rewards incidental to ownership of a leased asset lie with the lessor or the lessee (para. 7, HKAS 17). A lease is classified as a finance lease if it transfers substantially all the risks and rewards incidental to ownership (para. 8, HKAS 17). Title may or may not eventually be transferred (para. 4, HKAS 17). A lease is classified as an operating lease if it does not transfer substantially all the risks and rewards incidental to ownership (para. 8, HKAS 17). We will make use of the following illustrative example to discuss the accounting and tax consequences to the lessee and lessor when a lease is classified either as an operating or a finance lease.

\subsection{Illustrative Example}

Lessor Company (the lessor) manufactures an equipment with an estimated economic life of 5 years and leases it to Lessee Company (the lessee) for a period of 4 years. The lease is non-cancelable and there are no rights to extend the lease term or to purchase the equipment at the end of the term. Both companies are incorporated and have their business operations conducted in Hong Kong. The normal selling price of the equipment is $\$ 188,000$, and its unguaranteed residual value at the end of the lease term is estimated to be $\$ 20,000$. (Typically, the lessor purchases residual value insurance (RVI) from an independent third-party on this type of lease to protect it against unfavorable market movements between lease commencement and termination dates. Sometimes, RVI is also purchased to increase the minimum lease payments to $90 \%$ of the fair value of the equipment at lease inception in order to achieve finance lease treatment.)

Lessee Company will pay annual payments of $\$ 50,000$ at the beginning of each year and all maintenance and insurance. Lessor Company incurred costs of $\$ 135,000$ in manufacturing the equipment and $\$ 4,000$ in negotiating and closing the lease. At the end of the lease term, the lessee has to return the equipment in a satisfactory condition. If the lessee terminates the lease early, the lessee must pay a termination penalty, equal to the remaining minimum lease payment due under the lease contract plus any loss incurred by the lessor in remarketing the leased equipment.

Lessor Company has determined that the collectibility of the lease payments is reasonably predictable, that no additional costs will be incurred, and that the implicit interest rate is $10 \%$. The lessee is also aware of the lessor's implicit interest rate. Both companies adopt straight line depreciation method for their depreciable assets.

Minimum lease payments are the payments over the lease term that the lessee is or can be required to make, 
excluding contingent rent, costs for services and taxes to be paid by and reimbursed to the lessor, together with: (a) for a lessee, any amounts guaranteed by the lessee or by a party related to the lessee; or (b) for a lessor, any residual value guaranteed to the lessor (para. 4, HKAS 17).

The interest rate implicit in the lease is the discount rate that, at the inception of the lease, causes the aggregate present value of (a) the minimum lease payments and (b) the unguaranteed residual value to be equal to the sum of (i) the fair value of the leased asset and (ii) any initial direct costs of the lessor. However, initial direct costs do not include incremental costs that are directly attributable to negotiating and arranging a lease incurred by manufacturer or dealer lessors (para. 4, HKAS 17).

Referring to the illustrative example, the implicit interest rate of $10 \%$ will cause the sum of (a) and (b) to equal the fair value of the leased asset.

(a) Minimum lease payments

Present value of an annuity due for 4 periods at $10 \%$

X 3.4868

Present value of the minimum lease payments

$\$ 174,340$

(b) Unguaranteed residual value

$\$ 20,000$

Present value of 1 in 4 years at 10\%

$\mathrm{X} \quad 0.6830$

Present value of the unguaranteed residual value 13,660

Fair value of the leased asset

$\$ 188,000$

\section{Leases in the Financial Statements of Lessees}

\subsection{Operating Leases}

Lease payments under an operating lease shall be recognized as an expense on a straight-line basis over the lease term unless another systematic basis is more representative of the time pattern of the user's benefit (para. 33, HKAS 17). If the above lease is classified as an operating lease, the annual rental payments of $\$ 50,000$ will be charged to rental expense over the lease term.

\subsection{Finance Leases}

Whether a lease is a finance lease or an operating lease depends on the substance of the transaction rather than the form of the contract (see HK(SIC)-Int 27). HKAS 17 specifies some examples of situation that individually or in combination would normally lead to a lease being classified as a finance lease (para. 10, HKAS 17):

(a) the lease transfers ownership of the asset to the lessee by the end of the lease term (a transfer of title);

(b) the lessee has the option to purchase the asset at a price that is expected to be sufficiently lower than the fair value at the date the option becomes exercisable for it to be reasonably certain, at the inception of the lease, that the option will be exercised (a bargain purchase option);

(c) the lease term is for the major part of the economic life of the asset even if title is not transferred;

(d) at the inception of the lease the present value of the minimum lease payments amounts to at least substantially all the fair value of the leased asset; and

(e) the leased asset is of such a specialized nature that only the lessee can use it without major modifications.

Referring to the facts in the illustrative example, there is no transfer of title at the end of the lease term and no bargain purchase option is available. The lease term is four years which covers $80 \%$ of the economic life (five years) of the equipment. A lease is classified as a finance lease if it transfers substantially all the risks and rewards incidental to ownership (para. 8, HKAS 17), and title may or may not eventually be transferred (para. 4, HKAS 17). For Lessee Company, the lease is a finance lease because: (1) the lease term is for the major part $(80 \%)$ of the economic life of the equipment, and (2) the present value of the minimum lease payments $(\$ 174,340)$ amounts to substantially $(93 \%)$ all the fair value $(\$ 188,000)$ of the leased equipment.

Table 1 shows the lease amortization schedule for Lessee Company. At the commencement of the lease term, Lessee Company shall recognize the finance lease as asset and liability in the balance sheet at amounts equal to the fair value of the leased equipment or, if lower, the present value of the minimum lease payments, each determined at the inception of the lease. The discount rate to be used in calculating the present value of the minimum lease payments is the interest rate implicit in the lease, if this is practicable to determine; if not, the lessee's incremental borrowing rate shall be used (para. 20, HKAS 17).

Minimum lease payments shall be apportioned between the finance charge and the reduction of the outstanding 
liability. The finance charge shall be allocated to each period during the lease term so as to produce a constant periodic rate of interest on the remaining balance of the liability (para. 20, HKAS 17).

Initial obligation under the finance lease is calculated as follows:

Minimum lease payments

Present value of an annuity due for 4 periods at 10\% (3.4868)

x 3.4868

Present value of the minimum lease payments

A finance lease gives rise to depreciation expense for the leased equipment as well as finance expense for each accounting period. The depreciation policy for depreciable leased assets shall be consistent with that for depreciable assets that are owned, and the depreciation recognized shall be calculated in accordance with HKAS (IAS) 16 Property, Plant and Equipment. If there is no reasonable certainty that the lessee will obtain ownership by the end of the lease term, the asset shall be fully depreciated over the shorter of the lease term and its useful life (para. 27, HKAS 17).

The balance sheet for Year 1 will show a long-term asset of leased equipment at $\$ 174,340$ as reduced by the accumulated depreciation at $\$ 43,585(\$ 174,340 \div 4)$, and a lease liability at $\$ 124,340$ (spilt into current and non-current portions).

\subsection{Comparison of Finance Lease with Operating Lease}

From a cash flow point of view, Lessee Company is in the same position whether the lease is accounted for as an operating or a finance lease. Table 2 shows the comparison of finance lease with operating lease for Lessee Company. While the total expenses are the same over the lease term whether the lease is accounted for as a finance lease or an operating lease, the expenses are higher in the earlier years and lower in the later years under the finance lease treatment. In addition, using the finance lease approach results in an asset and a related liability of $\$ 174,340$ initially reported on the balance sheet. Lessee Company would not report any asset or liability under the operating lease method.

Thus, many companies believe that finance leases negatively impact their financial position. Their debt to equity ratio increases due to an increase in the amount of reported debt (both short-term and long-term). Their rate of return on total assets decreases due to an increase in the amount of total assets (specifically long-lived assets). A lower income will be reported in the early life of the lease and, therefore, lower retained earnings. Hence, capitalization of finance leases can more easily lead to violation of loan covenants, making the company less attractive to present and potential investors. As a result, the business community resists capitalizing finance leases.

\section{Leases in the Financial Statements of Lessors}

\subsection{Operating Leases}

Lessors shall present assets subject to operating lease in their balance sheet according to the nature of the asset (para. 49, HKAS 17). Lease income from operating leases shall be recognized in income on a straight-line basis over the lease term, unless another systematic basis is more representative of the time pattern in which use benefit derived from the leased asset is diminished (para.50, HKAS 17).

If the lease in the illustrative example is classified as an operating lease, the annual rental receipts of $\$ 50,000$ will be included as rental revenue over the lease term.

Initial direct costs incurred in negotiating and arranging an operating lease shall be added to the carrying amount of the leased asset and recognized as an expense over the lease term on the same basis as the lease income (para. 52, HKAS 17). The deprecation policy for depreciable leased assets shall be consistent with the lessor's normal depreciation policy for similar assets, and depreciation shall be calculated in accordance with HKAS (IAS) 16 (para. 53, HKAS 17).

\subsection{Finance Leases}

A lease is classified as a finance lease if it transfers substantially all the risks and rewards incidental to ownership (para. 8, HKAS 17), and title may or may not eventually be transferred (para. 4, HKAS 17). Referring to the facts in the illustrative example, the lease is a sales-type finance lease for Lessor Company because: (1) the lease term (four years) is for the major part ( $80 \%$ ) of the economic life (five years) of the equipment, (2) the present value of the minimum lease payments $(\$ 174,340)$ amounts to substantially $(93 \%)$ all the fair value $(\$ 188,000)$ of the leased equipment, and (3) Lessor Company realized an element of profit aside from the financing charge.

Table 3 shows the lease amortization schedule for Lessor Company. At the commencement of the lease term, Lessor Company shall recognize an asset held under a finance lease in the balance sheet and present it as a receivable at an 
amount equal to the net investment in the lease (para. 36, HKAS 17). Net investment in the lease is the gross investment in the lease discounted at the interest rate implicit in the lease. Gross investment in the lease is the aggregate of: (a) the minimum lease payments receivable by the lessor under a finance lease, and (b) any unguaranteed residual value accruing to the lessor (para. 4, HKAS 17).

Lease receivable at inception of the finance lease is calculated as follows:

(a) Minimum lease payments

$\$ 50,000$

Present value of an annuity due for 4 periods at $10 \%$

Present value of the minimum lease payments

(b) Unguaranteed residual value

Present value of 1 in 4 years at 10\%

$\times \quad 3.4868$

$\$ 20,000$

$\underline{\mathrm{x}} \mathbf{0 . 6 8 3 0}$

Present value of the unguaranteed residual value

Net investment in the lease

$\$ 188,000$

The recognition of finance income shall be based on a pattern reflecting a constant periodic rate of return on the lessor's net investment in the finance lease (para. 39, HKAS 17).

Lessor Company, as a manufacturer, shall recognize selling profit or loss in the period, in accordance with the policy followed by the entity for outright sales. Costs incurred in connection with negotiating and arranging a lease shall be recognized as an expense when the selling profit is recognized (para. 42, HKAS 17). Manufacturers or dealers often offer to customers the choice of either buying or leasing an asset. The finance lease of the equipment by Lessor Company in the illustrative example gives rise to two types of income: (a) profit or loss equivalent to the profit or loss resulting from an outright sale of the asset being leased, at normal selling prices; and (b) finance income over the lease term (para. 43, HKAS 17).

\subsection{Comparison of Finance Lease with Operating Lease}

From a cash flow point of view, Lessor Company is in the same position whether it accounts for the lease as an operating or a finance lease. Table 4 show the comparison of finance lease with operating lease for Lessor Company. While total revenues are the same over the lease term whether the lease is accounted for as a finance lease or an operating lease, the revenues are higher in the earlier years and lower in the later years under the finance lease treatment. The situation is even extreme with the immediate recognition of the sales profit. Finance lease treatment allows the lessor to recognize more earnings in the earlier periods of the lease, as compared to operating lease treatment, as well as finance leases can be sold in transfers such as securitizations. As such, lessors, especially manufacturers and dealers, may favor capitalizing leases.

\section{Sale and Leaseback Transactions}

A sale and leaseback transaction involves the sale of an asset and the leasing back of the same asset. The lease payment and the selling price are usually interdependent because they are negotiated as a package. The accounting treatment of a sale and leaseback transaction depends upon the type of lease involved (para. 58, HKAS 17). If a sale and leaseback transaction results in an operating lease, and it is clear that the transaction is established at fair value, any profit or loss shall be recognized immediately (para. 61, HKAS 17).

Assume that the equipment in the illustrative example is originally owned by Lessee Company with a cost of $\$ 135,000$ and is sold to Lessor Company at $\$ 188,000$ immediately before the inception of the lease. The profits of $\$ 53,000$ can be recognized immediately by Lessee Company if the subsequent lease results in an operating lease and it is clear that the transaction is established at fair value.

However, if a sale and leaseback transaction results in a finance lease, any excess of sales proceeds over the carrying amount shall not be immediately recognized as income by a seller - the lessee. Instead, it shall be deferred and amortized over the lease term (para. 59, HKAS 17). Thus, the profits of $\$ 53,000$ cannot be recognized immediately by Lessee Company if the subsequent lease results in a finance lease and will be deferred and amortized over the lease term, i.e. four years.

\section{Tax Consequences of Buying or Leasing an Asset}

Under the Hong Kong Inland Revenue Ordinance (IRO), a taxpayer who incurs capital expenditure on the provision of plant or machinery which is used to produce profits chargeable to profits tax is entitled to depreciation allowance in the form of initial allowance equal to $60 \%$ of the cost of the asset, and annual allowance equal to $10 \%, 20 \%$ or $30 \%$ of the tax written down value of the asset (section 39B of the IRO). This will give the taxpayer a total first year 
depreciation allowance of $64 \%, 68 \%$ or $72 \%$ of the asset cost. Assuming a profits tax rate of $16.5 \%$, the taxpayer can reduce his tax bill for the first year by an amount equal to $10.56 \%, 11.22 \%$ or $11.88 \%$ of the asset cost. In addition, any interest incurred on a loan obtained to finance the asset is deductible, provided that sections 16(1)(a) and (2) of the IRO are satisfied. On the other hand, if a taxpayer leases an asset instead of buying it, he is not entitled to depreciation allowance; but he can claim lease rentals as a deductible expense under section 16(1) of the IRO (Hui, 2006; Lau, 1997; Olesnicky, 1992).

If the finance rates which a taxpayer is offered on a borrowing and a lease are the same, it would be better to buy than to lease the asset as the taxpayer can enjoy accelerated tax benefits through high depreciation allowances in the first year. However, if he cannot enjoy the benefit of high depreciation allowances, such as he has tax losses brought forward, or he is not subject to tax, it will make sense to lease the asset than to buy it. The accelerated tax benefits can be enjoyed by the leasing company, the tax savings of which (as illustrated in Table 5) can then be passed on to the lessee in the form of reduced rental.

For tax purposes, a lease is defined in section 2 of the IRO as any arrangement under which a right to use a plant or machinery is granted by a person to another person; but does not include a hire-purchase agreement or a conditional sale agreement unless the right under the agreement to purchase or obtain the property in the goods would reasonably be expected not to be exercised. No matter whether an asset is held under a finance lease or an operating lease, legally the asset belongs to the lessor; and the tax treatments are the same. As owner of the asset, the leasing company is entitled to depreciation allowance, and is assessed on the rental income. The lessee is entitled to deduct the lease payment as an allowable expense. For tax purpose, there is no recognition of interest revenue for a lessor and interest expense for a lessee as shown in the accounting treatment for a finance lease.

\subsection{Tax Treatments for Lessees}

In the illustrative example, irrespective of whether the lease is classified as an operating lease or a finance lease, Lessee Company will be entitled to deduct the annual lease payment of $\$ 50,000$ as an allowable expense. It is however, not entitled to any depreciation allowance even if the asset is leased under a finance lease and recognized as an asset in its balance sheet. As a result, from a tax perspective, the classification of lease is most likely tax neutral.

\subsection{Tax Treatments for Lessors}

Similarly, the tax treatments for the lessors are not affected by the classification of the lease. In the illustrative example, irrespective of whether the lease is classified as an operating lease or a finance lease, Lessor Company legally owns the asset. It is entitled to deduct depreciation allowance and initial direct cost incurred in negotiating and arranging the lease (assuming that the initial direct cost is revenue in nature), and is assessed on the lease income. Assuming the asset qualifies for an annual allowance of $30 \%$, the tax position of Lessor Company is shown in Table 5.

\subsection{A Special Case of Finance Lease - Hire Purchase Leases}

As defined in section 2 of the IRO, a hire purchase agreement is an agreement for the bailment of goods under which the bailee may buy the goods, or under which the property in the goods will or may pass to the bailee. Examples of hire purchase leases are where the lessee has an option to purchase the leased goods, or if the lease agreement provides that title will pass automatically to the lessee upon payment of the last lease instalment, as in the case of a conditional sales agreement.

For tax purposes, a lessee under a hire purchase lease is treated as tax owner of the leased asset, and is entitled to deprecation allowance under section 37A of the IRO, but only on the capital portion of the lease payment. The interest portion of the lease payment is a deductible expense provided that sections 16(1)(a) and (2) of the IRO are satisfied.

Legally speaking, the lessor under a hire purchase lease is the owner during the lease term until title passes to the lessee, and arguably the lessor is entitled to deprecation allowance of the leased asset. However, in practice, the lessor is treated for tax purposes as having sold the asset for which he receives a rental payment comprising an instalment of purchase price and interest. The lessor is taxed on the interest earned, and on the profit made on sale (if the profit is on revenue account), based on accounting treatment in accordance with revenue recognition (IAS/HKAS 18 Revenue).

\subsection{Sale and Leaseback Transactions}

The tax treatment of a sale and leaseback transaction is very different from the accounting treatment. If a taxpayer sells a plant or machinery it owns to a leasing company and leases it back, irrespective of whether the lease is 
classified as a finance lease or an operating lease, the leasing company is not entitled to any deprecation allowance; unless the asset is sold to the leasing company for a price not exceeding the original price paid by the lessee to the supplier, and the lessee has not previously claim any depreciation allowance (section 39E of the IRO). Even if the leasing company is denied of depreciation allowance, the rental income could possibly be taxable. On the other hand, even if the lease is classified as a finance lease, the lessee cannot claim any depreciation allowance, but any profit made on sale of the asset is not taxable (if the profit is on capital account) and the lessee is entitled to deduct the lease payment as an allowable expense.

\section{Influence on Business Decisions - Buy or Lease}

The decision as to the method by which an asset is acquired is a complex issue. From an accounting perspective, as illustrated in Table 2, to buy (including arrangement through a finance lease) or to lease (through an operating lease) an asset will result in the same total cash outflow. From a tax perspective, it would be better to buy than to lease an asset as companies can enjoy accelerated tax benefits through high depreciation allowances in the first year, which will reduce their tax bills and hence cash outflows in the earlier years. It would seem that the buy option will be a better one. However, under the buy option (through a finance lease arrangement), companies have to report an asset and a liability, which may have a negative impact on their debt to equity ratio and rate of return on total assets. As total expenses under a finance lease are higher for the earlier years (as illustrated in Table 2), a lower income and hence lower retained earnings will be reported. Therefore, companies with high debt to equity ratio, low rate of return on total assets or low retained earnings may prefer to lease (through an operating lease).

Moreover, if a company cannot enjoy the benefit of high depreciation allowances, the lease option will be better than the buy option. The accelerated tax benefits can be enjoyed by the leasing company, the tax savings of which can then be passed on to the lessee in the form of reduced rental.

\section{Latest Development in Lease Accounting}

Since leasing is now a major international industry and a very important source of finance for a wide range of entities, the IASB and the FASB (the US standards setter), have started a joint project on leasing. The concern is that under the current lease accounting, huge amounts of leasing obligations are not shown on companies' balance sheets because the existing accounting standards require a clear cut classification between operating and finance leases. For finance leases, the whole of the leased item is capitalized on the lessee's balance sheet with the lease payment obligations being recognized as liabilities. For operating leases, all rentals are recognized as expenses as they accrue over the term of the lease. This works well for leases that meet the capitalization tests, where the arrangement is similar to the outright purchase of the leased asset. As the leasing industry has developed more complex contract terms, small differences in the lease terms can change the lease from an on-balance-sheet finance lease to an off-balance-sheet operating lease.

The primary objective of the IASB-FASB project is to develop a model for the recognition and measurement of assets and liabilities arising under lease contracts. They have issued a discussion paper Leases - Preliminary Views in March 2009 to solicit comments. There is a suggested new approach to lease accounting, called the "right-of-use" model (MacKintosh, 2007). This approach could be applied to all leases. At the beginning of the lease term, the objectives for lessees should be to record the fair value of the rights and obligations that are conveyed by the leases. Leases that are now characterized as operating leases would give rise to assets and liabilities - but only to the extent of the fair value of the rights and obligations that are conveyed by the leases and this will usually be less than the asset's full value. For a long term lease, the right of use will often be similar to the rights acquired by an outright purchase of the asset. For a shorter lease, the value of the right of use, and the amount capitalized, will be significantly less. In each case, the rentals to which the lessee is committed would be recognized as a liability of the lessee, but for very short leases, the rentals would often be immaterial and therefore not capitalized. Under the suggested approach, the lessee is required to recognize on its balance sheet the right it has acquired to use the leased asset for the lease term and the problem of arbitrary classification of operating and finance leases would be avoided.

\section{Conclusions}

Leasing is a vital issue for a wide range of companies, and the drastically different accounting and tax consequences of buying or leasing an asset strongly influence the business's decision as to the method by which an asset is acquired. The current practice of lease accounting for lessees and lessors is prescribed by IAS/HKAS 17 Leases. The appropriate accounting policies and disclosure to apply in relation to leases depend on the classification of leases. A lease is classified as a finance lease if it transfers substantially all the risks and rewards incidental to ownership; otherwise, a lease is classified as an operating lease. The lessees shall recognize the finance lease as asset and liability in the balance sheet at amounts equal to the fair value of the leased asset or, if lower, the present value of the minimum lease payments at the inception of the lease. Lease payments under an operating lease shall be recognized 
as an expense. However, small differences in lease terms can change the lease from a finance lease to an operating lease and there will be understatement of lease obligations and assets on the balance sheets. The Accounting Standards Board has long argued for the need to revise lease accounting and has played an important role in seeking the development of a new international standard. The "right-of-use model" suggests that all leases would give rise to assets and liabilities to lessees at the inception of the lease term to the extent of the fair value of the rights and obligations that are conveyed by the leases. The suggested model is conceptually sound and may provide a good basis for a new leasing standard that would make a major improvement in the quality of financial reporting.

\section{References}

Abdel-khalik, A.R. (1981). "The economic effects on lessees of FASB Statement No. 13, Accounting for Leases", FASB: Stamford, CT.

Beattie, V., A. Goodacre and S.J. Thomson. (1998). "The impact of constructive operating lease capitalization on key accounting ratios", Accounting and Business Research, Vol. 28, No. 4, 233-254.

Beattie, V., A. Goodacre and S.J. Thomson. (2000). "Operating leases and the assessment of lease-debt substitutability", Journal of Banking and Finance, Issue No. 24, 427-470.

Beattie, V., A. Goodacre and S.J. Thomson. (2006). "International lease-accounting reform and economic consequences: The views of UK users and preparers", The International Journal of Accounting, Vol. 41, No. 1, 75-103.

Beaver, W., P. Kettler and M. Scholes. (1970). "The association between market determined and accounting determined risk measures", The Accounting Review, Vol. 45, No. 4, 654-682.

Bowman, R.G. (1980). "The debt equivalence of leases: An empirical investigation", The Accounting Review, Vol. 55, No. 2, 237-253.

Breton, G. and R. Taffler. (1995). "Creative accounting and investment analyst response”, Accounting and Business Research, Vol. 25, No. 98, 81-92.

Broke, A. (1995). “Accounting Standards and Taxable Profit: An Accountant's View”, British Tax Review, Issue No. 5, 457-460.

Crosby, N. (2003). "Accounting for leases - the problem of rent reviews in capitalizing lease liabilities", Journal of Property Investment \& Finance, Vol. 21, No. 2, 79-108.

El-Gazzar, S. (1993). "Stock market effects of closeness to debt covenant restrictions resulting from capitalization of leases", The Accounting Review, Vol. 68, No. 2, 258-272.

Ely, K.M. (1995). "Operating lease accounting and the market's assessment of equity risk", Journal of Accounting Research, Vol. 33, No. 2, 397-415.

Finnerty, J.E., R.N. Fitzsimmons and T.W. Oliver. (1980). "Lease capitalization and systematic risk", The Accounting Review, Vol. 55, No. 4, 631-639.

Freedman, J. (1995). "Defining Taxable Profit in a Changing Accounting Environment", British Tax Review, Issue No. 5, 434-444.

Freedman, J. (2004). "Aligning Taxable Profits and Accounting Profits: Accounting Standards, Legislators and Judges", eJournal of Tax Research, Vol. 2, No. 1, 71-99.

Godfrey, J. and S. Warren. (1995). "Lessee reactions to regulation of accounting for leases", Abacus, Vol. 31, No. 2, 201-228.

Goodacre, A. (2003). "Operating lease finance in the UK retail sector", International Review of Retail, Distribution and Consumer Research, Vol. 13, No. 1, 99-125.

Gopalakrishnan, V. and M. Parkash. (1996). "The debt-equivalency of recognized vs. disclosed obligations: an examination of borrower and lender perceptions", Research in Accounting Regulation, Issue No. 10, 63-77.

Green, S. (1995). “Accounting Standards and Tax Law: Complexity, Dynamism and Divergence", British Tax Review, Issue No. 5, 445-451.

Hartman, B.P. and H. Sami. (1989). "The impact of accounting treatment of leasing contracts on user decision making: a field experiment", Advances in Accounting, Issue No. 7, 23-35.

Hong Kong Institute of Certified Public Accountants. (2004). "Hong Kong Accounting Standard 16 Property, Plant and Equipment”, Hong Kong Financial Reporting Standards (HKFRSs). Volume II Members' Handbook. 
Hong Kong Institute of Certified Public Accountants. (2004). "Hong Kong Accounting Standard 17 Leases", Hong Kong Financial Reporting Standards (HKFRSs). Volume II Members' Handbook.

Hong Kong Institute of Certified Public Accountants. (2004). "Hong Kong Accounting Standard 18 Revenue", Hong Kong Financial Reporting Standards (HKFRSs)., Volume II Members' Handbook.

Hong Kong Institute of Certified Public Accountants (2004). "Hong Kong Accounting Standard Interpretation 27 Evaluating the Substance of Transactions Involving the Legal Form of a Lease", Hong Kong (SIC). Interpretations (HK(SIC).-Int)., Volume II Members' Handbook.

Hui, A. (2006). "Tax Issues Associated with Plant and Machinery under Lease Agreements", Asia-Pacific Journal of Taxation, Vol. 10, No. 2, Summer, 2-6.

Imhoff, E., R. Lipe and D. Wright. (1991). "Operating leases: Impact of constructive capitalization", Accounting Horizons, Vol. 5, No. 1, 51-63.

Imhoff, E., R. Lipe and D. Wright. (1993). "The effects of recognition versus disclosure on shareholder risk and executive compensation”, Journal of Accounting, Auditing and Finance, Vol. 8, No. 4, 335-368.

Imhoff, E. and J.K. Thomas. (1988). "Economic consequences of accounting standards: The lease disclosure rule change", Journal of Accounting and Economics, Vol. 10, No. 4, 277-310.

Inland Revenue Ordinance (Chapter 112)., available at http://www.justice.gov.hk/eng/home.htm.

Johnson, J.M, R.J. Dowen and C.L. Norton. (1993). "An assessment of lessor accounting for residual values", Accounting Horizons, Vol. 7, No. 3, 55-65.

Lau, J. H. Y. (1997). "Aircraft Financing and Tax-based Leasing”, Asia-Pacific Journal of Taxation, Vol. 1, No. 4, Winter, 88-101.

Macdonald, G. (1995). "Matching Accounting and Taxable Profits: Reflections on Gallagher v. Jones", British Tax Review, Issue No. 5, 484-498.

MacKintosh, I. (2007). "Lease Accounting”, Accounting and Business, April, 30-32.

Martin, J., P. Anderson and A. Keown, Jr. (1979). "Lease capitalization and stock price stability: Implications for accounting", Journal of Accounting, Auditing \& Finance, Vol. 2, No. 2, 151-163.

Murray, D. (1982). “The irrelevance of lease capitalization”, Journal of Accounting, Auditing \& Finance, Vol. 5, No. 2, 154-159.

Olesnicky, M. (1992). "Tax Consequences of Leasing”, Technical Guidance, Hong Kong Society of Accountants, Vol. 14, No. 5, October, 23-26.

Powers, M. and L. Revsine (1989). "Lessor's accounting and residual values: Comdisco, Barron's, and GAAP”, The Accounting, Review, Vol. 64, No. 2, 346-368.

Sallabank, C. and N. Woodgate (1995). "Finance Lease Rental Payments and Statement of Practice 3/91: The Views of the Inland Revenue as Expressed in the Tax Bulletin”, British Tax Review, Issue No. 5, 506-510.

Standard \& Poor's (2002). Corporate Ratings Criteria New York, NY: Standard \& Poor's, available at http://www.standardpoor.com.

Whittington, G. (1995). “Tax Policy and Accounting Standards”, British Tax Review, Issue No. 5, 452-456.

Table 1. Lease Amortization Schedule for Lessee Company

\begin{tabular}{|c|c|c|c|c|}
\hline Beginning of Year & Annual Lease Payment (a) & $\begin{array}{c}\text { Interest (10\%) on Lease } \\
\text { Liability (b) }\end{array}$ & $\begin{array}{c}\text { Reduction of Lease } \\
\text { Liability (c) }\end{array}$ & Lease Liability (d) \\
\hline Initial PV & - & - & - & $\$ 174,340$ \\
\hline 1 & $\$ 50,000$ & - & $\$ 50,000$ & $\$ 124,340$ \\
\hline 2 & $\$ 50,000$ & $\$ 12,434$ & $\$ 37,566$ & $\$ 86,774$ \\
\hline 3 & $\$ 50,000$ & $\$ 8,678$ & $\$ 41,322$ & $\$ 45,452$ \\
\hline 4 & $\$ 50,000$ & $\underline{\$ 4,548 *}$ & $\underline{\$ 45,452}$ & - \\
\hline
\end{tabular}

*Rounding error is $\$ 2$.

(a) Annual lease payment required by lease contract.

(b) Preceding balance of (d) $\times 10 \%$, except beginning of first year of lease term. 
(c) (a) minus (b).

(d) Preceding balance minus (c).

Table 2. Comparison of Finance Lease with Operating Lease for Lessee Company

\begin{tabular}{|c|c|c|c|c|c|}
\hline & \multicolumn{3}{|c|}{ Finance Lease } & \multirow{2}{*}{$\begin{array}{c}\text { Operating Lease } \\
\text { Rental Expense (b) }\end{array}$} & \multirow{2}{*}{$\frac{\text { Difference }}{\text { (a) }- \text { (b) }}$} \\
\hline Year & Depreciation Expense & Interest Expense & Total Expenses (a) & & \\
\hline 1 & $\$ 43,585$ & $\$ 12,434$ & $\$ 56,019$ & $\$ 50,000$ & $\$ 6,019$ \\
\hline 2 & $\$ 43,585$ & $\$ 8,678$ & $\$ 52,263$ & $\$ 50,000$ & $\$ 2,263$ \\
\hline 3 & $\$ 43,585$ & $\$ 4,548$ & $\$ 48,133$ & $\$ 50,000$ & $(\$ 1,867)$ \\
\hline 4 & $\$ 43,585$ & $=$ & $\underline{\$ 43,585}$ & $\$ 50,000$ & $(\$ 6,415)$ \\
\hline & $\$ 174,340$ & $\$ 25,660$ & $\$ 200,000$ & $\$ 200,000$ & $\underline{0}$ \\
\hline
\end{tabular}

Table 3. Lease Amortization Schedule for Lessor Company

\begin{tabular}{|c|c|c|c|c|}
\hline Beginning of Year & $\begin{array}{c}\text { Annual Lease Payment Plus } \\
\text { Residual Value (a) }\end{array}$ & $\begin{array}{c}\text { Interest }(10 \%) \text { on Lease } \\
\text { Receivable (b) }\end{array}$ & $\begin{array}{c}\text { Lease Receivable } \\
\text { Recovery (c) }\end{array}$ & $\begin{array}{c}\text { Lease Receivable } \\
\text { (d) }\end{array}$ \\
\hline Initial PV & - & - & - & $\$ 188,000$ \\
\hline 1 & $\$ 50,000$ & - & $\$ 50,000$ & $\$ 138,000$ \\
\hline 2 & $\$ 50,000$ & $* \$ 13,800$ & $\$ 36,200$ & $\$ 101,800$ \\
\hline 3 & $\$ 50,000$ & $\$ 10,180$ & $\$ 39,820$ & $\$ 61,980$ \\
\hline 4 & $\$ 50,000$ & $\$ 6,198$ & $\$ 43,802$ & $\$ 18,178$ \\
\hline End of 4 & $\underline{\$ 220,000}$ & $* \underline{\$ 1,822 *}$ & $\underline{\$ 18,178}$ & - \\
\hline
\end{tabular}

*Rounding error is $\$ 4.00$.

(a) Annual lease payment $(\$ 50,000)$ required by lease contract and unguaranteed residual value $(\$ 20,000)$.

(b) Preceding balance of (d) $\mathrm{x} 10 \%$, except beginning of first year of lease term.

(c) (a) minus (b).

(d) Preceding balance minus (c).

Table 4. Comparison of Finance Lease with Operating Lease for Lessor Company

\begin{tabular}{|c|c|c|c|c|c|}
\hline & \multicolumn{3}{|c|}{ Finance Lease } & Operating Lease & Difference \\
\hline Year & Net Sales Profit & Interest Revenue & Total Income (a) & Net Rental Revenue (b) & (a) - (b) \\
\hline 1 & $\$ 49,000^{*}$ & $\$ 13,800$ & $\$ 62,800$ & $\$ 20,250^{* *}$ & $\$ 42,550$ \\
\hline 2 & - & $\$ 10,180$ & $\$ 10,180$ & $\$ 20,250$ & $(\$ 10,070)$ \\
\hline 3 & - & $\$ 6,198$ & $\$ 6,198$ & $\$ 20,250$ & $(\$ 14,052)$ \\
\hline 4 & $=$ & $\underline{\$ 1,822}$ & $\underline{\$ 1,822}$ & $\underline{\$ 20,250}$ & $\underline{(\$ 18,428)}$ \\
\hline & $\underline{\$ 49,000}$ & $\underline{\$ 2,000}$ & $\underline{\$ 81,000}$ & $\underline{\$ 81,000}$ & $\underline{0}$ \\
\hline
\end{tabular}

* Sales price $\$ 174,340$ - Cost of sales $\$ 121,340$ [ $\$ 135,000$ (cost of the asset) - $\$ 13,660$ (the present value of the unguaranteed residual value of $\$ 20,000)$ ] - Initial direct costs $\$ 4,000$

** Rental Revenue $\$ 50,000$ - Depreciation $\$ 29,750[(\$ 135,000+\$ 4,000-\$ 20,000) \div 4]$

Table 5. Tax Position of Lessor Company

\begin{tabular}{|c|c|c|c|c|c|}
\hline Year & Initial Allowance (a) & Annual Allowance (b) & $\begin{array}{c}\text { Initial Direct Costs } \\
\text { (c) }\end{array}$ & $\begin{array}{c}\text { Lease Rental } \\
\text { Income (d) }\end{array}$ & $\begin{array}{c}\text { Assessable Profit/ } \\
\text { (Allowable Loss) (e) }\end{array}$ \\
\hline 1 & $\$ 81,000$ & $\$ 16,200$ & $\$ 4,000$ & $\$ 50,000$ & $(\$ 51,200)$ \\
\hline 2 & - & $\$ 11,340$ & & $\$ 50,000$ & $\$ 38,660$ \\
\hline 3 & - & $\$ 7,938$ & & $\$ 50,000$ & $\$ 42,062$ \\
\hline 4 & $=$ & $\underline{\$ 5,557}$ & $\underline{=}$ & $\underline{\$ 50,000}$ & $\underline{\$ 44,443}$ \\
\hline & $\underline{\$ 1,000}$ & $\underline{\$ 41,035}$ & $\underline{\underline{\$ 4,000}}$ & $\underline{\$ 200,000}$ & $\underline{\underline{\$ 73,965}}$ \\
\hline
\end{tabular}
(a) Manufacturing cost of $\$ 135,000 \times 60 \%$.
(b) Tax written down value (cost as reduced by initial and annual allowances) x $30 \%$.
(e) (d) minus (a), (b) and (c). 